\title{
A Note on Translations and Abbreviations
}

Throughout this book I have cited available English translations of the French and German works. Page references are first to the original edition and then to the translation (e.g., Capital, p. 53/74); both versions are included in the Works Cited (pp. I69-8I). I have silently altered the translations when necessary for greater precision. Any translations not cited in this way are my own.

For convenience, I have used the following abbreviations to refer to frequently cited works in the body of the text. Full bibliographic information can be found in the Works Cited.

AP Honoré de Balzac, "Avant-Propos" to The Human Comedy

Capital Karl Marx, Capital: A Critique of Political Economy

LI Honoré de Balzac, Lost Illusions

LL $\quad$ Honoré de Balzac, Louis Lambert

PP Charles Dickens, The Posthumous Papers of the Pickwick Club

$S B \quad$ Charles Dickens, Sketches by Boz

UM Honoré de Balzac, "The Unknown Masterpiece" 



\section{Writing in Parts \\ Imitation and Exchange in \\ Nineteenth-Century Literature}


